\title{
REPORT UPON THE ECHINI COLLECTED BY THE U. S. FISH COM- MISSION STEAMER ALBATROSS IN THE GULF OF MEXICO FROM JANUARY TO MARCH, 1885.
}

\section{IBY RECHA TRE RATHEUN.}

\section{NOTICE OF THE CRUISE OF 1885.}

The U. S. Fish Commission steamer Albatross left Norfolk, Va., January, 1885, on a second winter's cruise to the Gulf of Mexico, this time solely in the interest of the Fish Commission, and for the purpose of exploring the fishing grounds lying off the southern coast of the United States. These grounds had never been previously investigated, and the only information we possessed respecting their character and extent had been obtained from the fishermen. On the trip to Key West the Albatross spent one day fishing with trawl lines off South Carolina, in depths of about 80 to 100 fathoms, but stormy weather interfering with the continuation of the work in that latitude, it was abandoned for the time being.

At Key West the important fishing interests centering in that place were studied with great care, and thence the Albatross proceeded to Havana, Cuba, spending about four days on the famous Pentacrinus ground located off Havana light, a portion of the party at the same time making a brief examination of the fisheries and fishing craft of the region. 'The next localities visited were the island of Cozumel and Campeche Bank, off Yucatan, where seines and hand-lines were employed in making collections of fishes with a view to obtaining information respecting the migrations and spawning habits of certain species of fishes that also inhabit our own coast. The remainder of the cruise, excepting about two weeks spent at New Orleans, was devoted to exploring the fishing grounds of the northeastern part of the Gulf of Mexico, from the mouth of the Mississippi River to Cedar Keys, Fla., and from the latter place to the Dry Tortugas. The principal fishery of this region is for the red snapper, and the most satisfactory results regarding the distribution and habits of that species were obtained between Tampa Bay and the Dry Tortugas, in depths of 25 to 28 fathoms. The shore fisheries at the mouth of Manatee River, Florida, were also studied, and the existence of a reported bank outside of the 100 -fathom line off Mobile was disproved.

The investigations were all carried on with extreme thoroughness, and included many lines of temperature observations and dredgings across the fishing grounds to ascertain their chief characteristics. In this manner many valuable collections of fishes and invertebrates were obtained, and they are now safely stored at the National Museum, where they are being studied. One hundred and ten dredging stations (serial 
numbers 2311 to 2420 , inclusive) were made, in depths of 21 to 1,467 fathoms, the deepest series, ranging from 730 to 1,467 fathoms, being located directly south of Mobile. On the return trip several lines of serial temperatures were carried out from the capes of Virginia across the area in which the schools of mackerel and menhaden first appear at the beginning of their spring migrations toward the north; and it is believed that a continuance of these observations through several years will afford some clue to the changes observed in the movements of these fish from year to year. An account of the practical results obtained on this cruise will soon be published.

Lieut.-Commander Z. L. Tanner, U. S. N., was in command of the expedition, with Capt. J. W. Collins in charge of the practical fishery investigations, and Mr. James E. Benedict chief naturalist, assisted by Mr. Willard Nye, jr., and Mr. Thomas Lee. Dr. T. H. Bean, curator of the department of fishes in the National Museum, also accompanied the steamer during the first half of the cruise, and Mr. Silas Stearns, of Pensacola, Fla., made two trips to the red-snapper grounds.

Of the group of Echini, or sea urchins, 31 species were collected in suitable condition for determination, being 8 more than were obtained in the same region the previous winter. These represent 78 dredging stations, with depths of 21 to 1,330 fathoms, only one species having been obtained in shore collecting, viz., at the island of Cozumel. Seventeen species were additional to those collected in 1884, and 9 of the species collected in 1884 were not obtained in 1885. The total number of species obtained on these two cruises was 40. I am indebted to Mr. Alexander Agassiz for assistance in making some of the identifications. The numbers in parentheses refer to the Radiate catalogue of the U. S. National Museum.

List of the stations at which Echini were collected in 1885.

OFF SOUTH CAROLINA.

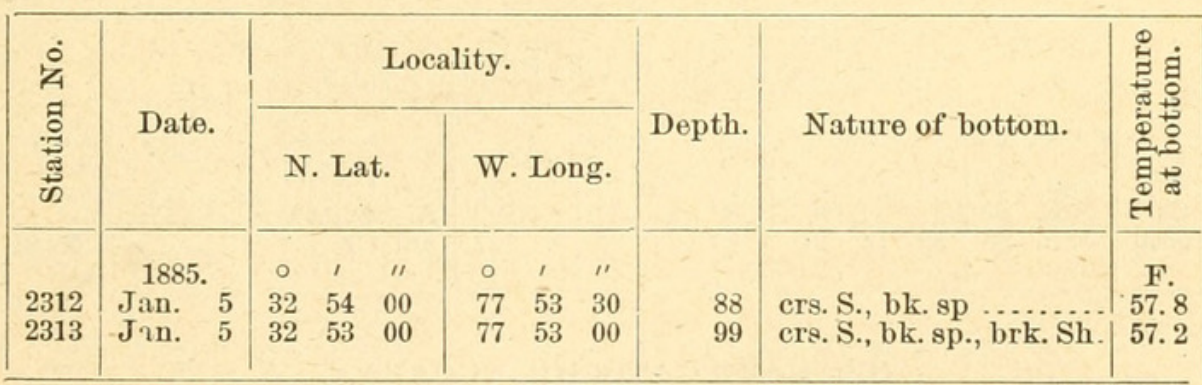

OFF KEY WEST, FLA.

\begin{tabular}{|c|c|c|c|c|c|c|c|c|c|c|c|}
\hline 2315 & Jan. & 15 & 24 & 26 & 00 & 81 & 48 & 15 & 37 & $\mathrm{Cr} \ldots$ & \\
\hline 2316 & Jan. & 15 & 24 & 25 & 30 & 81 & 47 & 45 & 50 & & 74 \\
\hline 2317 & Jan. & 15 & 24 & 25 & 45 & 81 & 46 & 45 & 45 & $\mathrm{Cr} \ldots \ldots$ & 75 \\
\hline 2318 & Jan. & 15 & 24 & 25 & 45 & 81 & 46 & 00 & 45 & Cr $\ldots \ldots \ldots \ldots \ldots$ & 75 \\
\hline
\end{tabular}


List of the stations at which Echini were collected in 1885-Continued.

OFF HAVANA, CUBA.

\begin{tabular}{|c|c|c|c|c|c|c|c|c|c|c|}
\hline \multirow{2}{*}{ 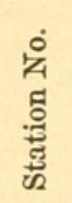 } & \multirow{2}{*}{ Date. } & \multicolumn{6}{|c|}{ Locality. } & \multirow{2}{*}{ Depth. } & \multirow{2}{*}{ Nature of bottom. } & \multirow{2}{*}{ 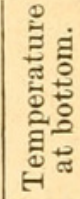 } \\
\hline & & \multicolumn{3}{|c|}{ N. Lat. } & \multicolumn{3}{|c|}{ W. Long. } & & & \\
\hline & 1885. & 0 & & $\prime \prime$ & $\circ$ & , & $\prime \prime$ & & & F. \\
\hline 2319 & Jan. 17 & 23 & 10 & 37 & 82 & 20 & 06 & 143 & gy. Cr....... & $\ldots$. \\
\hline 2320 & Jan. 17 & 23 & 10 & 39 & 82 & 18 & 48 & 130 & 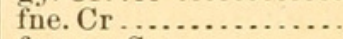 & $\ldots$. \\
\hline 2321 & Jan. 17 & 23 & 10 & 54 & 82 & 18 & 00 & 230 & 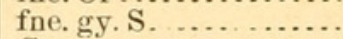 & ...... \\
\hline 2322 & Jar. 17 & 23 & 10 & 54 & 82 & 17 & 45 & 115 & $\mathrm{Cr} \ldots \ldots \ldots$ & $\ldots . .$. \\
\hline 2323 & Jan. 17 & 23 & 10 & 51 & 82 & 19 & 03 & 163 & wh. Cr .................... & \\
\hline 2324 & Jan. 17 & 23 & 10 & 25 & 82 & 20 & 24 & 33 & $\mathrm{Cr} \ldots \ldots$ & 79.1 \\
\hline 2325 & Jan. 17 & 23 & 10 & 48 & 82 & 19 & 54 & 170 & Cr $\ldots \ldots \ldots \ldots \ldots \ldots$ & $\ldots .$. \\
\hline 2326 & Jan. 17 & 23 & 11 & 45 & 82 & 18 & 54 & 194 & $\mathrm{Cr} \ldots \ldots \ldots \ldots \ldots$ & 62 \\
\hline 2327 & Jan. 17 & 23 & 11 & 45 & 82 & 17 & 54 & 182 & fne. bn. S............. & $\ldots .$. \\
\hline 2330 & Jan. 17 & 23 & 10 & 48 & 82 & 19 & 15 & 121 & fne. gy. Cr ........... & ...... \\
\hline 2331 & Jav. 17 & 23 & 10 & 31 & 82 & 19 & 55 & 114 & 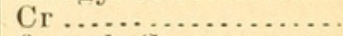 & $\ldots .$. \\
\hline 2333 & Jan. 19 & 23 & 10 & 36 & 82 & 19 & 12 & 169 & fne. wh. Cr........... & ..... \\
\hline 2334 & Jan. 19 & 23 & 10 & 42 & 82 & 18 & 24 & 67 & wh. Cr $\ldots \ldots \ldots \ldots \ldots$ & ..... \\
\hline 2335 & Jan. 19 & 23 & 10 & 39 & 82 & 20 & 21 & 204 & 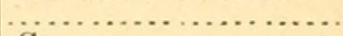 & $\cdots$ \\
\hline 2336 & Jan. 19 & 23 & 10 & 48 & 82 & 18 & 52 & 157 & .......... & ...... \\
\hline 2337 & Jan. 19 & 23 & 10 & 39 & 82 & 20 & 21 & 199 & .......... & $\ldots$. \\
\hline 2338 & Jan. 19 & 23 & 10 & 40 & 82 & 20 & 15 & 189 & $\ldots \ldots \ldots \ldots$ & ...... \\
\hline 2341 & Jan. 19 & 23 & 11 & 00 & 82 & 19 & 06 & 143 & $\ldots \ldots \ldots \ldots \ldots$ & $\ldots \ldots$ \\
\hline 2342 & Jan. 19 & 23 & 10 & 39 & 82 & 20 & 21 & 201 & Cr $\ldots \ldots \ldots \ldots \ldots \ldots$ & \\
\hline 2343 & Jan. 19 & 23 & 11 & 35 & 82 & 19 & 25 & 279 & fne. Cr . . . . . . . . . . & \\
\hline 2345 & Jan. 20 & 23 & 10 & 40 & 82 & 20 & 15 & 184 & fne.gy. wh. Cr....... & ...... \\
\hline 2346 & Jan. 20 & 23 & 10 & 39 & 82 & 20 & 21 & 200 & Cr $\ldots \ldots \ldots \ldots \ldots \ldots$ & \\
\hline 2347 & Jan. 20 & 23 & 10 & 39 & 82 & 20 & 21 & 216 & Cr $\ldots \ldots \ldots \ldots \ldots \ldots$ & \\
\hline 2348 & Jan. 20 & 23 & 10 & 39 & 82 & 20 & 21 & 211 & Cr $\ldots \ldots \ldots \ldots \ldots \ldots$ & \\
\hline 2349 & Jan. 20 & 23 & 10 & 40 & 82 & 20 & 15 & 182 & Cr $\ldots \ldots \ldots \ldots \ldots \ldots$ & \\
\hline 2350 & Jan. 20 & 23 & 10 & 39 & 82 & 20 & 21 & 213 & Cr $\ldots \ldots \ldots \ldots \ldots$ & \\
\hline
\end{tabular}

OFF WEST COAST OF CUBA.

\begin{tabular}{|c|c|c|c|c|c|c|c|c|c|c|}
\hline 2351 & Jan. 21 & 22 & 41 & 00 & 84 & 16 & 30 & 426 & & \\
\hline 2352 & Jan. 21 & 22 & 35 & 00 & 84 & 23 & 00 & 463 & wh. Cr $\ldots \ldots \ldots \ldots \ldots$ & 45 \\
\hline
\end{tabular}

OFF ARROWSMITH BANK, YUCATAN.

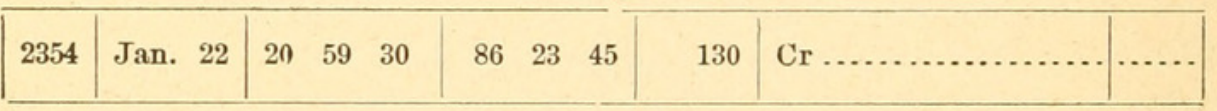

OFF COZUMEL ISLAND, YUCATAN.

\begin{tabular}{|c|c|c|c|c|c|c|c|c|c|c|}
\hline 2357 & Jan. 29 & 20 & 19 & 00 & 87 & 03 & 10 & 178 & wh. Cr ..... & \\
\hline 2358 & Jan. 29 & 20 & 19 & 00 & 87 & 03 & 30 & 222 & fne. wh. Cr ........... & $\ldots .$. \\
\hline 2359 & Jan. 29 & 20 & 19 & 10 & 87 & 03 & 30 & 231 & 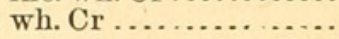 & 50.8 \\
\hline
\end{tabular}

OFF CAPE CATOCHE, YUCATAN.

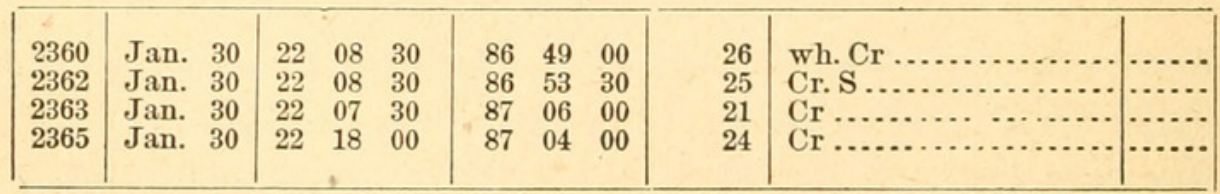




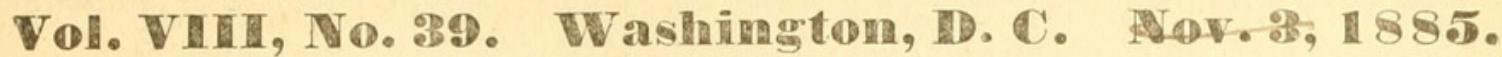

List of the stations at which Echini were collected in 1885-Continued.

BETWEEN LOUISIANA AND CEDAR KEYS, FLA.

\begin{tabular}{|c|c|c|c|c|c|c|c|c|c|c|}
\hline \multirow{2}{*}{ 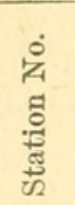 } & \multirow{2}{*}{ Date. } & \multicolumn{6}{|c|}{ Locality. } & \multirow{2}{*}{ Depth. } & \multirow{2}{*}{ Nature of bottom. } & \multirow{2}{*}{ 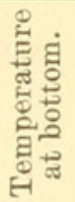 } \\
\hline & & \multicolumn{3}{|c|}{ N. Lat. } & \multicolumn{3}{|c|}{ W. Long. } & & & \\
\hline & 1885. & $\circ$ & & $" \prime$ & $\circ$ & 1 & & & & $\mathrm{E}$. \\
\hline 2369 & Feb. 7 & 29 & 16 & 30 & 85 & 32 & & 26 & crs. gy. S. brk. Sh . & \\
\hline 2370 & Feb. & 29 & 18 & 15 & & 32 & & 25 & crs. gy. S. brk. Sh & \\
\hline 2371 & Feb. & 29 & 17 & 00 & 5 & 30 & & 26 & gy. S. brk. Sh ... & 65.8 \\
\hline 2372 & Feb. & 29 & 15 & 30 & 85 & 29 & & 27 & & \\
\hline 2373 & Feb. & 29 & 14 & 00 & 85 & 29 & & 25 & & \\
\hline 2374 & Feb. & 29 & 11 & 30 & 85 & 29 & & 26 & S. G. brk. Sh ... & \\
\hline 2375 & Feb. 7 & 29 & 10 & 00 & 85 & 31 & 00 & 30 & S. bk. sp. brk. Sl & \\
\hline 2376 & Feb. 11 & 29 & 03 & 15 & 88 & 16 & 00 & 324 & gy. M............. & 46.5 \\
\hline 2378 & Feb. 11 & 29 & 14 & 30 & 88 & 09 & 30 & 68 & ...... do & \\
\hline 2381 & Mar. 2 & 28 & 05 & 00 & 87 & 56 & 15 & 1,330 & lt. bn. M . & \\
\hline 2383 & Mar. 3 & 28 & 32 & 00 & 88 & 06 & 00 & 1,181 & n. M & 39.8 \\
\hline 2384 & Mar. & 28 & 45 & 00 & 8 & 15 & 30 & 940 & у. M.. & 39.6 \\
\hline 2385 & Mar. 3 & 28 & 51 & 00 & 88 & 18 & 00 & 730 & gy. M.... & 40.1 \\
\hline 2388 & Mar. 4 & 29 & 24 & 30 & & 01 & & 35 & il. S. bk. sp .... & \\
\hline 2392 & Mar. 13 & 28 & 47 & 30 & 87 & 27 & 0 & 724 & br. gy. M......... & 40.7 \\
\hline 2393 & Mar. 13 & 28 & 43 & 00 & & 14 & & 525 & lt. gy. M ........ & 41.1 \\
\hline 2395 & Mar. 13 & 28 & 36 & 15 & 86 & 50 & 0 & 347 & gy. М $\ldots \ldots \ldots \ldots$ & 44.1 \\
\hline 2400 & Mar. 14 & 28 & 41 & 00 & 86 & 07 & 00 & 169 & do. & \\
\hline 240 & Mar. 14 & 28 & 38 & 30 & 85 & 52 & 3 & 14 & gn. M. brk. Sh..... & \\
\hline 240 & Mar. 14 & 28 & 36 & 00 & 85 & 33 & 30 & 111 & $\operatorname{gy} . \mathrm{M} . . .$. & \\
\hline 240 & Mar. 15 & 28 & 42 & 30 & 85 & 29 & 0 & 88 & $\ldots$ do $\ldots \ldots$. & \\
\hline 2404 & Mar. 15 & 28 & 44 & 00 & 85 & 16 & $0 c$ & 60 & gy. S.. & \\
\hline 2405 & Mar. 15 & 28 & 45 & 00 & 85 & 02 & 0 & 30 & gy. S., brk. Cr ... & \\
\hline 2406 & Mar. 15 & 28 & 46 & 00 & 84 & 49 & 00 & 26 & ers. S. Cr...... & \\
\hline 240 & Mar. 15 & 28 & 47 & 30 & 84 & 37 & 00 & 24 & Cr. brk. Sh... & \\
\hline 2408 & Mar. 16 & 28 & 28 & 00 & 84 & 25 & 00 & 21 & $\mathrm{Cr} \ldots \ldots \ldots \ldots \ldots \ldots$ & \\
\hline
\end{tabular}

BETWEEN TAMPA BAY AND DRY TORTUGAS, FLA.

\begin{tabular}{|c|c|c|c|c|c|c|c|c|c|c|}
\hline 2409 & Mar. 18 & 27 & 04 & 00 & 83 & 21 & 15 & 26 & crs. gy. S. brk. Sh & \\
\hline & Mar. 18 & 26 & 47 & 30 & 83 & 25 & & 28 & f. wh.s. bk. sp. brk. & \\
\hline 2411 & Mar. 18 & 26 & 33 & 30 & 83 & 15 & 30 & 27 & f. wh. S. bk. sp ......... & \\
\hline 2412 & Mar. 19 & 26 & 18 & 30 & 83 & 08 & 45 & 27 & $\begin{array}{l}\text { fne. gy. S. bk. sp. brk. } \\
\text { Sh }\end{array}$ & \\
\hline 2413 & Mar. 19 & 26 & 00 & 00 & 82 & 57 & 30 & 24 & fne. S. bk. sp. brk. Sh.. & \\
\hline 2414 & Mar. 19 & 25 & 04 & 30 & 82 & 59 & 15 & 26 & f. wh. S. brk. Sh . & \\
\hline
\end{tabular}

OFF ATLANTIC COAST OF SOUTHERN STATES.

\begin{tabular}{|l|ll|lll|lll|r|r|r|}
\hline 2415 & Apr. & 1 & 30 & 44 & 00 & 79 & 26 & 00 & 440 & Cr. ers. S. Sh. Foram .. & 45.6 \\
2417 & Apr. & 2 & 33 & 18 & 30 & 77 & 07 & 00 & 95 & fne. gy. S............. & 65.8 \\
2418 & Apr. & 2 & 33 & 20 & 00 & 77 & 05 & 00 & 90 & g. S. S. . . . . . . . . . . & 65.8 \\
2420 & Apr. & 5 & 37 & 03 & 20 & 74 & 31 & 40 & 104 & bk. S. M. G.......... & 47.7 \\
\hline
\end{tabular}

ACCOUNT OF THE SPECIES OF ECHINI OBTAINED IN 1885.

Cidaris tribuloides Blainv.

A fine series of large specimens was collected at station 2407, 24 fathoms (10734). Small to inedium-sized specimens were obtained from the following localities: Station 2315, 37 fathoms (10702); station 2316, 50 fathoms (10703); station 2324, 33 fathoms (10701); station 2342, 201 fathoms; station 2363, 21 fathoms (10700); stations 2372, 2373, 2374,

Proc. Nat. Mus. 85 
depth 25-27 fathoms (10697); stations 2405, 2407, 24-30 fathoms (10699); station 2408, 21 fathoms (10696); station 2414, 26 fathoms (10698).

The large specimens from station 2407 , above mentioned, have long and rather pointed spines, and in nearly all cases more or less of the spines were overgrown with clusters of small barnacles, bryozoa, worm tubes and shells. Fully one half the specimens were infested with a species of Stylifer, which was generally found boring into the spines, although in one case a single specimen was seen attached to the test, near the base of a spine, having made there a slight burrow. As many as seven spines were sometimes thus affected in a single specimen, but the usual number was from three to five. The spines attacked were mostly toward the upper surface, but not always so, and were generally those of small to medium size.

The borings of the Stylifer produce a curious effect. A small, round hole is first formed in the side of the spine near its base, and the irritation apparently induces a continuous deposition of shelly matter, which increases in size until it forms a prominent globular protuberance completely surrounding the spine at the point of irritation. On one side the protuberance is more or less deeply hollowed out, and may contain anywhere from one to eight shells. The spines become stunted in growth, and seldom have more than a small point projecting above the excrescence. The upper part of the protuberance with the tip of the spine may finally break away, leaving the opening to the cavity at the outer end of an abrupt enlargement of the spine. The boring generally takes place at the lower end of the spines, frequently just above the base. In a few instances there are quite regular globular terminations to short spines without much of a cavity, or with none at all, and these have probably been produced by a deposition of shelly matter over the burrows after the stylifers had left them.

The protuberances range in size from a very slight enlargement to twice the diameter of the base of the spine, and are frequently quite grotesque in shape and in the appearance of the concavity, the latter being often so large as to leave but a thin shell inclosing it. There are sometimes two or three openings to one protuberance. The outer surface generally resembles that of the smaller and smoother spines, but is occasionally covered with a coarse granulation. Its color is a rich brown to brownish black. The spines not infested by Stylifers are all perfectly normal.

A very small specimen from station 2372 had a single specimen of the same Stylifer upon one of the spines close to the abactinal system.

Dorocidaris Bartletti A. Agassiz.

Three fine large specimens were obtained from the following localities: Station 2326, 194 fathoms (10659); station 2331, 114 fathoms (10660); station 2335, 204 fathoms (10661). Young specimens were collected at stations 2327, 2337, depth 182, 199 fathoms (10707); and characteristic spines at the following stations: $2320,2322,2324,2325$, 
$2327,2330,2334,2349$, depth $33-182$ fathoms (10662). The young specimens collected at station 2138, depth 23 fathoms, 1884 (7479), and referred in the last report to Cidaris tribuloides, belong to this species.

The three larger specimens mentioned above came up in excellent condition, with most of the spines intact. The smallest of the three, from station 2335 , measured 28 millimeters in diameter; the largest, from station 2326, measured 68 millimeters in diameter; height, 50 millimeters; actinostome, 24 millimeters; apical system, 26 millimeters; length of longest radiole, 78 millimeters ; 9-10 primary interambulacral plates. The spines in all of these specimens exhibited every gradation in structure from the nearly smooth variety to those which are strongly spiny, the latter greatly predominating. In one of the specimens the genital plates are in contact at their inner ends, but in the others the ocular plates touch the anal.

Dorocidaris papillata A. Agassiz.

Typical specimens, mostly of small size, were obtained from the following localities: Stations 2319-2322, 2324, 2327, 2336, 2337, 2342, $2345,2346,2347,2348$, and 2349 , depth 33 to 230 fathoms (10710); station 2323, 163 fathoms (10709); station 2341, 143 fathoms (10708); station 2415,440 fathoms (10756).

A variety of this species, with slender, strongly serrated spines, described by Mr. Alexander Agassiz in his "Revision of the Echini," pages 256-257, was collected in very large numbers at each of the four following stations: 2316, 2317, 50 fathoms (10051); 2318, 45 fathoms $(10052,10712) ; 2418,90$ fathoms (10053). A few specimens of the same were also obtained at station 2334,67 fathoms $(10713) ; 2351,426$ fathoms (10711); 2372, 2373, 25-27 fathoms (10715); 2420, 104 fathoms (10714).

Of this variety the larger specimens measure about 32 millimeters in diameter, and all have long, very slender, tapering spines, equalling in length from one and one-half to three times the diameter of the test, the spines being usually proportionally longer in the smaller specimens. The general color of the test in alcoholic specimens is a pale yellowish, greenish, or buff; the secondary spines have each a broad band of dark pink through the center, which sometimes covers nearly the entire width of the spines. The primary spines in young specimens are generally greenish, and in the larger ones are grayish with a tinge of green; they are frequently banded. The abactinal system is violet or violet brown, the color varying much in intensity, the ocular plates being lighter thain the others.

Porocidaris Sharreri A. Agassiz.

Two large specimens were obtained from station 2354, 130 fathoms (10717); and one medium-sized specimen came from each of the three following localities: Station 2345, 184 fathoms (10706); station 2348, 211 fathoms (10705); station 2415, 440 fathoms (10704). Fragments of 
spines were dredged at stations 2337, 2338, 2341, 2360, depth 26-199 fathoms (10716).

The two specimens from stations 2345 and 2348 are very similar in appearance and of nearly the same size, the smaller measuring 27 millimeters in diameter. The spines are long, straight, and tapering, and of a pure white to a light pinkish and brownish-white color, with the bases of the delicate brownish-pink described by Mr. Alexander Agassiz. These spines are very finely striated, but appear smooth to the naked eye.

In the larger specimens from station 2354 , which are also both of about the same size (the larger measuring 51 millimeters in diameter) the spines are likewise slender, straight, very long, and gradually tapering, being very uniform in their general appearance over most of the two specimens. They are finely fluted, and the still finer striation of the surface is also apparent; the bases are of a rich reddish-brown, much darker than in the smaller specimens. Immediately beyond the base, the shaft becomes of a light green, which gradually changes to a deep pinkish, the two colors blending for a considerable distance. The pink becomes intensified outwardly generally to within about 10 to 20 millimeters of the tip, where it is frequently replaced abruptly by white, especially in the longer spines; sometimes it continues quite to the tip. The pink also produces a slight banding at times on the outer half of the spines. The longer spines measure from 150 to 155 millimeters in length; fully three times the diameter of the test. Some of the spines are slightly enlarged and hollowed out at the tip.

The specimen from station 2415 measures 18 millimeters in diameter. Salenia Pattersonii A. Agassiz.

Stations 2320, 2321, 2322, 2325, 2327, 2334, 2335, 2337, 2342, 2343, $2345,2346,2349$, depth $67-279$ fathoms (10649). One small specimen from station 2322, 115 fathoms (10652) had three specimens of a Stylifer attached to the dorsal surface.

Arbacia punctulata Gray.

All of the specimens obtained were young, the majority being quite small; they were collected at the following localities: Stations 2362, 2363,2365 , depth $21-25$ fathoms (10655); stations 2369 to 2373 , inclusive, 25-27 fathoms (10656); stations 2405 to 2409 , inclusive, $21-30$ fathoms (10657); stations 2412, 2413, 24-27 fathoms (10658).

Cœlopleurus floridanus A. Agassiz.

Station 2316, 50 fathoms (10653) ; stations 2319, 2320, 2322, 2327, 2331, 2334, 2335, 2337, 2342, 2347, 2348, depth 67-216 fathoms (10654).

Diadema setosum Gray.

Station 2333, 169 fathoms (10667), two small specimens; station 2363, 21 fathoms (10059), several large specimens; station 2405, 30 fathoms (10666), one small specimen; station 2138 (1884), 23 fathoms (8433), one very young specimen. 
Among the specimens from station 2363 are several with uniformly light colored spines, a sort of yellowish or dirty white color. These light spines are most common on the ventral surface, but sometimes also occur scattered among the dark spines of all parts of the test, producing a very curious effect. In one specimen nearly all the spines are white.

Aspidodiadema antillarum A. Agassiz.

Stations 2385, 2392, 2393, 525-730 fathoms (10663).

Aspidodiadema Jacobyi A. Agassiz.

Stations 2346, 2347, 2350, 200-216 fathoms (10664); station 2359, 231 fathoms (10665).

Asthenosoma hystrix A. Agassiz.

Station 2350, 213 fathoms (10673), two young specimens; station 2358,222 fathoms (10668), several large specimens, the largest measuring about 200 millimeters in diameter, in alcohol; station 2415, 440 fathoms (10674), small to medium size.

Phormosoma placenta Wyv. Thomson.

Station 2376,324 fathoms (10670) ; station 2383, 1181 fathoms (10671), fine series; station 2395,347 fathoms (10672).

Temnechinus maculatus A. Agassiz.

One living specimen from station 2370, 25 fathoms (10689), and dead specimens from the two following stations: 2372, 27 fathoms (10690); 2405,30 fathoms (10691).

\section{Trigonocidaris albida A. Agassiz.}

Stations 2321, 2327, 2341, 2342, 2343, 2349, depth 143-279 fathoms (10694); stations 2335, 2347, depth 204-216 fathoms (10695); station 2357, 178 fathoms (10692). The following from the Gulf of Mexico collections of 1884 were accidentally included in the last report among the young of the deep water variety of Toxopneustes variegatus: Station 2159, 98 fathoms (10693); station 2166, 196 fathoms (8414); station 2167,201 fathoms (8412).

Toxopneustes variegatus A. Agassiz.

Typical specimens were collected at the following localities: Station 2317,45 fathoms (10681); station 2362, 25 fathoms (10682); station 2407,24 fathoms (10683.) These specimens were mostly rather small, and of a pinkish color in alcohol, the test being darker than the spines.

The small deep-water form was obtained at the following localities: Station 2316, 50 fathoms (10687); station 2318, 45 fathoms (10685); stations $2326,2327,2335,2337,2338,2342,2345,2346,2349$, depth 182 204 fathoms (10686); station 2345, 184 fathoms (10684); station 2347, 216 fathoms (10688).

Hipponoë esculenta. A. Agassiz.

Cozumel Island, Yueatan (10669), a single specimen. 
Echinocyamus pusillus Van $\mathrm{Ph}$.

One living specimen from station 2352, 463 fathoms (10632); dead specimens from station 2342, 201 fathoms (10631); station 2354, 130 fathoms, and station 2359, 231 fathoms (10623).

Clypeaster Ravenellii A. Agassiz.

Station 2312, 88 fathoms (10055); station 2313, 99 fathoms (10056); station 2317, 45 fathoms (10675); station 2318, 45 fathoms (10643), one young specimen; station 2388, 35 fathoms (10054), a fine large series, containing over one hundred specimens; station 2403,88 fathoms (10057); station 2404, 60 fathoms $(10626,10644)$, young and dead fragments; station 2417, 95 fathoms (10058), ten specimens.

The largest specimen collected measured about 135 millimeters in diameter. This species was associated with Clypeaster subdepressus at stations 2317 and 2388. The majority of the specimens of C. subdepressus obtained were of small to medium size, and rather shorter in proportion to the width than in the more typical specimens; the width was frequently nearly equal to the length. There is, however, no diffculty in distinguishing these two species, even in very young specimens. In $C$. Ravenellii the length and width are always closely the same, excepting in abnormal specimens; the margins, in the interambulacral spaces, excepting in small specimens, are nearly always distinctly, and sometimes quite strongly, incurved, and the entire margin is considerably thickened. In some specimens of $C$. subdepressus the margin becomes slightly thickened, but never so much so as in $C$. Ravenellii.

The entire median portion of the test of $C$. Ravenellii, on the abactinal side, is greatly elevated, with rather abrupt though regularly arched slopes, extending about to the outer ends of the ambulacral petals. The petals are broadly open at their outer ends, and have the poriferous zones nearly parallel along the outer two-thirds of their length. The granulation of the test is much coarser than in C. subdepressus, and the principal granules much more widely separated. The coarse granulation of the actinal surface approaches less closely to the ambulacral furrows, which, especially in small specimens, are frequently bordered with broad comparatively smooth areas, reaching to near the margins of the test. The ambulacral turrows are deeper and broader. In nearly all the living specimens which have been denuded, the sutures between the plates on the abactinal surface are marked with purple, forming a network distinctly outlining the coronal plates, especially toward the margins. This color is sometimes continued over a portion of the actinal surface. The color of both dried and alcoholic specimens is a very bright greenish yellow, more or less uniform over both the upper and lower surfaces. Large specimens are sometimes less brightly colored than small ones.

The color of most of the alcoholic specimens of $O$. subdepressus, not denuded, was a dull grayish brown on the abactinal surface, the same color also marking the interambulacral spaces on the actinal surface, 
the ambulacral areas being of a dark, dull greenish color. Denuded specimens were purplish gray on the upper surface, and on the lower surface grayish in the interambulacral areas, and dull greenish in the ambulacral. Many specimens of this species were stored in the same tank with $C$. Ravenellii, and became strongly tinged with yellow, giving them at first sight the general appearance of the latter species.

In $C$. Ravenellii where the test has been injured by accident, the injured portion is frequently of a bright green color. The same color in several specimens from station 2417 surrounds small shallow circular cavities which appear to have been produced by some boring animal, perhaps a species of Stylifer, but no such forms were found attached.

\section{Clypeaster subdepressus Agassiz.}

Station 2317, 45 fathoms (10676); station 2362, 25 fathoms (10625), dead fragment; station 2375,30 fathoms (8995), a large series, mostly of small size, the largest measuring 90 millimeters in longitudinal diameter; station 2388, 35 fathoms (8992); station 2411, 27 fathoms (8994); station 2414, 26 fathoms (8993).

A few notes regarding this species are given under Clypeaster Ravenellii. One specimen from station 2375 had six ambulacral petals and furrows.

\section{Encope Michelini Agassiz.}

Station 2375,30 fathoms (8954); a very fine series, ranging in size from small to large, the largest measuring about 160 millimeters in both longitudinal and transverse diameters. The three anterior lunules in no case form more than slight indentations of the edge of the test. The interambulacral lunule is comparatively small, and the posterior ambulacral lunules are of about the same size, though never closed. The apex is frequently very prominent, that portion of the test bulging greatly. From station 2410, 28 fathoms (8955), a similar but smaller series was obtained. Fragments of dead specimens were dredged at station 2360, 26 fathoms (10621), and station 2362, 25 fathoms (10622).

Conolampas Sigsbei A. Agassiz.

Station 2350, 213 fathoms, three living specimens of medium size (10645), and one small dead specimen (10766); station 2342, 201 fathoms (10762), one very young living specimen.

Palæotropus Josephinæ Lovén.

Station 2327, 182 fathoms (10635), one specimen; station 2341, 143 fathoms (10634), 2 specimens.

Paleopneustes cristatus A. Agassiz.

Station 2332, 156 fathoms (10759), one small specimen; station 2336, 157 fathoms (10761), one fragment.

Paleopneustes hystrix A. Agassiz.

Station 2343, 279 fathoms (10648), one specimen, measuring 63 millimeters in longitudinal diameter. The spines are proportionally fewer 
in number and longer than in a specimen measuring 110 millimeters in length, some of them on the dorsal side being fully half as long as the test. The secondary spines are also much more widely scattered on the upper surface.

\section{Linopneustes longispirus A. Agassiz.}

Station 2343, 279 fathoms (10646), two specimens each measuring about 68 millimeters in length. The marginal fasciole is not colored differently from the rest of the test.

Hemiaster Mentzi A. Agassiz.

Station 2384, 940 fathoms (10647), one specimen measuring about 30 millimeters in length.

Brissopsis lyrifera Agassiz.

Station 2343, 279 fathoms (10636); station 2378, 68 fathoms (10637), fine series; station 2381, 1,330 fathoms (10638); station 2400, 169 fathoms (10639); station 2401, 142 fathoms (10640), fine series; station 2402, 111 fathoms (10627), dead fragment; station 2404, 60 fathoms (10633), one young specimen.

Agassizia excentrica A. Agassiz.

One living specimen from each of the two following stations : 2341 , 143 fathoms (10629); 2345, 184 fathoms (10630).

Metalia pectoralis A. Agassiz.

Station 2362, 25 fathoms (10624), fragments of a dead specimen.

Meoma ventricosa Lütken.

A fine series of this species was obtained from the following localities: station 2362, 25 fathoms (10619), dead fragment; station 2405, 30 fathoms (8996); station 2406, 26 fathoms (8997); station 2411,27 fathoms (9000); station 2412, 27 fathoms (8998); station 2414, 26 fathoms (8999).

Schiłzaster (Periaster) limicola A. Agassiz.

Station 2378, 68 fathoms (10641), 2 small specimens; station 2401, 142 fathoms (10642), 5 large specimens.

LISTS OF THE SPECIES OBTAINED IN 1884 AND 1885, ARRANGED ACCORDING TO LOCALITIES.

ATLANTIC COAST OF THE SOUTHERN STATES.

Off South Carolina; 88 to 99 fathoms, coarse and fine sand, broken shells. Stations 2312, 2313, 2417, 2418 (1885).

Dorocidaris papillata, var.

Clypeaster Ravenellii.

Off Fernandina, Fla.; 440 fathoms, coral, coarse sand, shells, \&c. Station 2415 (1885).

Dorocidaris papillata.

Porocidaris Sharreri.

Asthenosoma hystrix. 


\section{GULF OF MEXICO.}

Between the delta of the Mississippi River and Cedar Keys, Fla., 1885.

21 to 60 fathoms; sand, gravel, coral, broken shells ; stations 2369-2375, 2388, 24042408.

Cidaris tribuloides.

Dorocidaris papillata, var.

Arbacia punctulata.

Diadema setosum.

Temnechinus maculatus.

Toxopneustes variegatus.

Olypeaster Ravenellii.

Clypeaster subdepressus.

Encope Michelini.

Brissopsis lyrifera.

Meoma ventricosa.

68 to 169 fathoms; gray and green mud; stations 2378, 2400-2403.

Clypeaster Ravenellii.

Brissopsis lyrifera.

Schizaster (Periaster) limicola.

324 to 730 fathoms; gray mud; stations $2376,2385,2392,2393,2395$.

Aspidodiadema antillarum.

Phormosoma placenta.

940 to 1330 fathoms; mud; stations 2381, 2383, 2384.

Phormosoma placenta.

Hemiaster Mentzi.

Brissopsis lyrifera.

Between Tampa Bay and the Dry Tortugas, Florida; 24 to 28 fathoms, coarse and fine sand, and broken shells. Stations 2409-2414 (1885).

Cidaris tribuloides.

Arbacia punctulata.

Clypeaster subdepressus.

Encope Michelini.

Meoma ventricosa.

Off Key West, Fla.; 37 to 50 fathoms; coral bottom. Stations 23152318 (1885).

Cidaris tribuloides.

Dorocidaris papillata, var.

Colopleurus floridanus.

Toxopneustes variegatus.

Clypeaster Ravenellii.

Clypeaster subdepressus.

Off Havana, Cuba; 29 to 387 fathoms ; coral and sandy bottoms. Stations 2152-2154, 2157, 2159, 2161-2164, 2166, 2167 (1884); 2319-2327, 
2330, 2331-2338, 2341-2343, 2345-2350 (1885). These stations are mostly from $1 \frac{1}{2}$ to 5 nautical miles northeast of Havana Light, and from $\frac{1}{2}$ to $3 \frac{1}{2}$ miles off shore. A few, however, are about 2 miles northwest of the jight.

Fathoms.

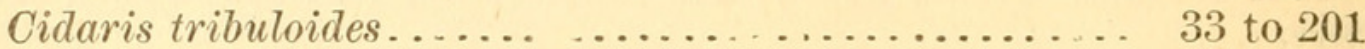

Dorocidaris Bartletti ....................... 33204

Dorocidaris Blakei ........................ $122 \quad 387$

Dorocidaris papillata .................... $29 \quad 387$

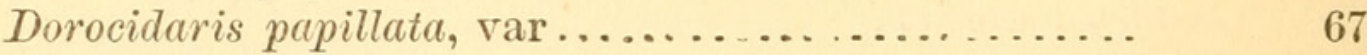

Porocidaris Sharreri........................... 143211

Salenia Pattersonii...................... $67 \quad 279$

Colopleurus floridanus.................... $67 \quad 216$

Diadema setosum .......................... 169

Aspidodiadema Jacobyi .................... $192 \quad 216$

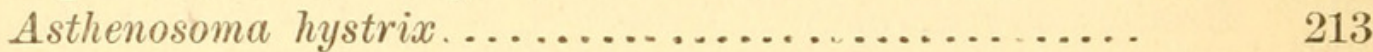

Trigonocidaris albida..................... $98 \quad 279$

Toxopneustes variegatus ................... $98 \quad 216$

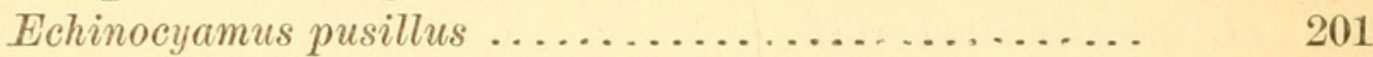

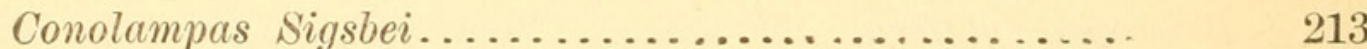

Palceotropus Josephince..................... 143182

Paleopneustes cristatus.................. $156 \quad 157$

Paleopneustes hystrix . . . . . . . . . . . . . . . . . . 279

Linopneustes longispinus. . . . . . . . . . . . . $29 \quad 279$

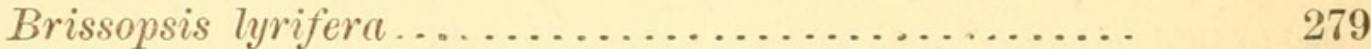

Agassizia excentrica ...................... $98 \quad 184$

Off the west coast of Cuba ; 426 to 463 fathoms ; coral bottom. Stations 2351, 2352 (1885).

Dorocidaris papillata, var.

Echinocyamus pusillus.

Off Cape Catoche, Yucatan; 21 to 26 fathoms, coral and sandy bottoms. Stations 2360, 2362, 2363, 2365 (1885).

Cidaris tribuloides.

Porocidaris Sharreri.

Arbacia punctulata.

Diadema setosum.

Toxopneustes variegatus.

Clypeaster subdepressus.

Encope Michelini.

Metalia pectoralis.

Meoma ventricosa.

CARIBBEAN SEA.

Off Arrowsmith Bank, Yucatan ; 130 fathoms, coral bottom. Station 2354 (1885).

Porocidaris Sharreri.

Echinocyamus pusillus. 
Off Cozumel Island, Yucatan; 178 to 231 fathoms, coral bottom. Stations 2357-2358 (1885).

Aspidodiadema Jacobyi.

Asthenosoma hystrix.

Trigonocidaris albida.

Echinocyamus pusillus.

Off Santiago de Cuba, near shore; 202 to 400 fathoms, mud, sand, hard coral. Stations 2128, 2129, 2131, 2134, 2135 (1884).

Dorocidaris Blakei.

Dorocidaris papillata.

Aspidodiadema Jacobyi.

Off southeast end of Cuba; 1,639 fathoms, greenish mud. Station 2127 (1884).

Salenia varispina.

Aspidodiadema antillarum.

Off Port Royal, Jamaica; 215 fathoms, black mud. Station 2139 (1884).

\section{Diadema setosum.}

Albatross Bank, between Jamaica and Hayti; 23 fathoms, corals and broken shells. Station 2138 (1884).

Cidaris tribuloides.

Dorocidaris Bartletti.

Diadema setosum.

Toxopneustes variegatus.

Off Aves Island; 683 fathoms, yellow mud, fine sand. Station 2117 (1884).

Salenia varispina.

Phormosoma placenta.

Homolampas fragilis.

Aceste bellidifera.

Off St. Vincent; 690 fathoms, gray mud. Station 2118 (1884).

Salenia varispina.

Off Gulf de Morrosquillo, United States of Colombia; 155 fathoms, green mud. Station 2143 (1884).

Aspidodiadema Jacobyi.

Phormosoma placenta.

Off Aspinwall, Panama; 25 to 34 fathoms, green mud, broken shells. Stations 2145, 2146 (1884).

Cidaris tribuloides.

Brissopsis lyrifera. 
Off Old Providence Island; 382 fathoms, coral sand. Station 2150 (1884).

Echinocyamus pusillus.

Aceste bellidifera.

SHORE STATIONS.

Key West, Fla :

Diadema setosum.

Echinometra subangularis.

Toxopneustes variegatus.

Hipропоё esculenta.

Echinanthus rosaceus.

Cape San Antonio, Cuba:

Toxopneustes variegatus.

Echinanthus rosaceus.

Cozumel Island, Yucatan:

Hipponoё esculenta.

Jamaica :

Echinometra viridis.

Toxopneustes variegatus.

Old Providence Island :

Diadema setosum.

Echinometra subangularis.

Hipponoë esculenta.

Mellita sexforis.

Sabanilla, United States of Colombia:

Cidaris tribuloides.

Echinometra subangularis.

Toxopneustes variegatus.

Hipponoё esculenta.

Encope emarginata.

Curaçao Island :

Diadema setosum.

Echinometra subangularis.

Toxopneustes variegatus.

Hipponoë esculenta.

St. Thomas :

Cidaris tribuloides.

Diadema setosum.

Echinometra subangularis.

Echinometra viridis.

Toxopneustes variegatus.

Hipponoё esculenta.

Echinanthus rosaceus. 


\section{$2 \mathrm{BHL}$ Biodiversity Heritage Library}

Rathbun, Richard. 1885. "Report upon the Echini collected by the U. S. Fish Commission steamer Albatross in the Gulf of Mexico from January to March, 1885." Proceedings of the United States National Museum 8(544), 606-620. https://doi.org/10.5479/si.00963801.544.606.

View This Item Online: $\underline{\text { https://www.biodiversitylibrary.org/item/52770 }}$

DOI: https://doi.org/10.5479/si.00963801.544.606

Permalink: https://www.biodiversitylibrary.org/partpdf/51019

\section{Holding Institution}

Smithsonian Libraries

\section{Sponsored by}

Smithsonian

\section{Copyright \& Reuse}

Copyright Status: Public domain. The BHL considers that this work is no longer under copyright protection.

This document was created from content at the Biodiversity Heritage Library, the world's largest open access digital library for biodiversity literature and archives. Visit BHL at https://www.biodiversitylibrary.org. 